Prof. dr. Remzija Hadžiefendić-Parić

\title{
Objasnidbene (eksplikativne) rečenice i nerečenične strukture s to jest (tj.) u bosanskom jeziku
}

Izvorni naučni rad

Sažetak

U radu se govori o semantičkim i strukturnim karakteristikama objasnidbenih rečeničnih (i nerečeničnih) konstrukcija prepoznatljivih po veznom sredstvu to jest ili, skraćeno, tj. Odlika im je značenje objasnidbenosti, naknadnosti, redefiniranja, preformulacije $i$ koordinacijski odnos (gramatička neovisnost).

$U$ radu se raspavlja o tome pripadaju li posebnoj vrsti eksplicitnih nezavisnosloženih rečenica (to jest/tj. morao bi biti formalni pokazatelj te pripadnosti, odnosno nezavisni veznik, konjunktor, karakterističan upravo za takve - objasnidbene - rečenice) ili su pak podvrsta implicitnih nezavisnosloženih rečenica $i$ to sastavnih (to jest/tj. ne bi imao status specifičnog nezavisnog rečeničnog veznika, već bi, po pravilu postponirana, klauza s tim veznim izrazom bila uvedena postupkom nizanja, ne uvrštavanja).

Rečenice s to jest/tj. česte su u tekstovima naučnog stila kao $i$ onima u kojima se nekom vrstom „ponavljanja“ - kao posljedicom svjesne namjere - postiže dopunska jasnost, preciznost ili svojevrsna korektivnost.

Ključne riječi: objasnidbena (eksplikativna) rečenica, redefiniranje, preformulacija, dopunjavanje, korektivnost, vezno sredstvo, veznik, to jest/tj., nezavisnosložena rečenica, naučni stil, publicistički stil.

\section{Nezavisnosložene rečenice}

Iako je savremena sitnaksa, a rekli bismo općenito moderna lingvistička teorija problematizirala mnoge tradicionalne postavke $\mathrm{u}$ toj oblasti (npr. rečenica kao komunikativna jedinica i kao jedinica teksta; predikativnost kao minimalni konstituent rečenice čiji je nosilac predikat i predikativnost kao odnos subjekta i predikata...), 
općeprihvaćena je podjela rečenica na nezavisnosložene (koordinirane) i zavisnosložene (subordinirane).

Kao općepoznatu, nove gramatike, udžbenička i priručna literatura prihvaćaju i potklasifikacija nezavisnosloženeih rečenica na tri vrste: sastavne (kopulativne), rastavne (disjunktivnne) i suprotne (adverzativne). Isključne (ekskluzivne) i zaključne (konkluzivne) rečenice, koje je tradicionalna gramatika izdvajala kao posebnu vrstu nezavisnosloženih, u novijim gramatikama uglavnom se više ne izdvajaju kao zasebne. ${ }^{1}$

Naime, polazeći od određenja rečenice kao jezičke jedinice $s$ gramatičkom obilježjem predikativnosti (ima potpunu unutrašnju gramatičku strukturu, kontekstualno je neuključena, nosi uopćeno značenje i, tako određena, stoji nasuprot iskazu kao govornoj jedinici, kontekstualno uključenoj, vezanoj za konkretan govorni čin zbog čega je bez obavezno eksplicirane unutarnje gramatičke strukture), složena rečenica (nasuprot kojoj stoji jednostavna, koja može biti jednočlana i dvočlana) određuje se kao rečenica sastavljena od dviju ili više surečenica/klauza. (Teorijska sintaksa uvela je i termin višestruko složena rečenica, ili period, za složene strukture sastavljene od triju ili više predikata, tj. surečenica/klauza).

\section{Rečenica}

-jezička jedinica

-ima potpunu gramatičku strukturu

-kontekstualno neuključena

-nosi (uopćeno) z n a č e nj e

(Ibrahim čita novine.)

\section{Iskaz}

-govorna jedinica

-ne mora imati potpunu gr. strukturu

-kontekstualno uključen

-nosi s mi s a o

(-Šta ćeš ti?

-Ne znam... Kahvu.)

Broj surečenica/klauza u složenoj određen je brojem predikata, odnosno broj predikata odgovara broju surečenica/klauza.

\footnotetext{
${ }^{1}$ I Gramatika bosanskog jezika (2000) izdvaja tri vrste nezavisnosloženih rečenica (sastavne, suprotne i rastavne), kao eksplicitne (odnos klauza obilježen veznicima) i implicitne (odnos klauza nije obilježen veznicima), str. 428-471. Ismail Palić, autor dijela Sintaksa u ovoj gramatici, isključne rečenice izdvaja kao podvrstu suprotnih implicitnih (bezvezničkih) nezavisnih rečenica (str. 466), a zaključne kao podvrstu sastavnih implicitnih rečenica (str. 418).
} 
Ako su klauze u nezavisnom odnosu (a takve su uvijek kad su gramatički ravnopravne, kad među njima ne postoji odnos sintaksičke obaveznosti), riječ je o nezavisnosloženoj rečenici, npr.:

Ibrahim čita novine i glasno komentira.

Ako cijelu (složenu) rečenicu označimo znakom R, a njene klauze s R1 i R2, dobit ćemo formulu:

$\mathrm{R}=\mathrm{R} 1+\mathrm{R} 2$

$\mathrm{R} 1=$ Ibrahim čita novine

$\mathrm{R} 2=i$ glasno komentira naslove.

Klauze su u nezavisnom odnosu po svojoj sintaksičkoj neobaveznosti u složenoj rečenici, a u sastavnom po (a) općem značenju 'sastavnosti' i 'istovrsnosti' ili 'paralelnosti' svojih sadražaja i (b) po vezniku $i$. Po smisaonom odnosu prema klauzi R1, klauza R2 sastavna je rečenica: radnje 'čitanja' i 'komentranja' sastavne su, paralelne.

Ako su klauze u zavisnom odnosu, tj. ako su $\mathrm{u}$ odnosu gramatičke zavisnosti (hijerarhijski strukturirane), riječ je o zavisnosloženoj rečenici:

Kad Ibrahim čita novine, glasno komentira naslove.

$\mathrm{R}=\mathrm{R} 1+\mathrm{R} 2$,

$\mathrm{R} 1=$ Kad Ibrahim čita novine

$\mathrm{R} 2$ = glasno komentira naslove.

Dakle, R1 je zavisna klauza po tome što nije samostalna $\mathrm{u}$ odnosu na R2 (ne može se osamostaliti u tekstu) i to vremenska (temporalna): određuje vrijeme radnje označne predikatom komentira u glavnoj klauzi (R2) i ima veznik kad.

\section{Kriteriji klasifikacije}

Klasifikacija nezavisnosloženih rečenica, temelji se na određenim kriterijima. To su: (1) značenje (semantički odnos svake pojedinačne rečenice različit od semantičkog odnosa ostalih vrsta nezavisnosloženih rečenica) i (2) formalne karakteristike (veznici i vezna sredstva kao načini izražavanja njihovog posebnog semantičkog 
odnosa, tj. gramatikalizirana sredstva veze klauza kao gramatički pokazatelji takvog odnosa, gramatički konektori posebni za svaku pojedinu vrstu veza među klauzama nezavisnosloženih rečenica).

\section{Isključne i zaključne rečenice}

Kada je teorija jasno izdvojila kriterije klasifikacije (značenje i gramatička sredstva izražavanja), postao je upitan vrsni status isključnih (Svi su došli, samo nije on) i zaključnih rečenica (Položio je sve ispite do sada, stoga će sigurno položiti i ovaj!).

Novija sintaksička istraživanja pokazala $u$, naime, da se ovakve rečenice ne mogu smatrati posebnom vrstom nezavisnosloženih rečenica $s$ obzirom na njihovo značenje (zaključnosti i isključnosti), podvedivo pod opće značenje sastavnih i suprtonih rečenica (1. uvjet izdvajanja u posebnu vrstu), ali i s obzirom na odsustvo posebnih gramatičkih koordiniranih veznika specijaliziranih upravo za izražavanje samo takvih (zaključnih i isključnih) značenjskih odnosa (2. uvjet izdvajanja).

Naime, u isključnim rečenicama riječi samo, jedino i sl. ne mogu se smatrati gramatikaliziranim sredstvima veze, tj. veznicima, budući da povezivanje i nije njihova osnovna i bitna funkcija. ${ }^{2}$ Istina, uz opće značenje suprotnosti među sadržajima ovih klauza (doći nasuprot ne doći) postoji i komponenta 'isključivosti' (iz kvantifikatora $s v i$ 'svi do jednog, bez izuzetka' isljučen on 'samo jedan'), ali naglašena prilogom, ne veznikom, samo (up. Svi su došli, samo nije on. i rečenicu u kojoj se suprotnost gramatikalizira ako se klauze spoje suprotnim veznikom: Svi su došli, ali nije on).

Isto je sa zaključnim rečenicama, samo što su one podvedive pod opće značenje sastavnih rečenica ('opća sastavnost') kao jedna od njihovih podvrsta ${ }^{3}$, a prilozi stoga, dakle i sl. nisu posebna gramatikalizirana vezna sredstva izražavanja odnosa tih rečenica, pa nisu zaključni koordinirani veznici.

${ }^{2}$ Up. I. Pranjković, Koordinacija u hrvatskom književnom jeziku, Zagreb, 1984; M. Kovačević, Sintaksa složene rečenice u srpskom jeziku, Beograd, 1998.

${ }^{3}$ Up. I. Pranjković, Koordinacija...., str. 71-72. 
Tumačene na taj način, ni isključne ni zaključne rečenica nemaju status vrste, već podvrste suprotnih ${ }^{4}$, odnosno sastavnih rečenica pa ih, s obzirom na njihov značenjski odnos sa surečenicama, i naše novije gramatike bosanskog jezika tako izdvajaju: zaključne kao podvrstu sastavnih, a isključne kao podvrstu suprotnih. ${ }^{5}$ Kao takve, u novijim se gramatikama i jedne i druge uvrštavaju u implicitne (asindetske) nezavisne rečenice (up. Gramatika bosanskog jezika 2000:418-418).

\section{Gradacijske rečenice}

Novije gramatike i udžbeničko-priručne literatura bosanskog, kao i hrvatskog i srpskog jezika, ${ }^{6}$ među nezavisnosložene rečenice ponegdje izdvajaju i gradacijske, pri čemu se kao njihovi veznici navode veznički izrazi a kamoli i (ne) samo...nego (već), tj. spoj priloga (ne) samo i veznika suprotnih rečenica nego i već.

Obično se smatraju posebnom vrstom nezavisnosloženih rečenica ${ }^{7}$ ili su, što je češće - ako se već o njima govori, izdvojene kao podvrsta suprotnih ${ }^{8}$ budući da svoj specifični odnos 'uporednosti' i 'gradacije' povezuju veznicima tipičnim za suprotne rečenice a, nego, već: Čovjek osjeća potrebu ne samo da misli već $i$ da kaže...(v. Grmatika bosanskog jezika 2000:416), tj. povezuju se korelativnim vezničkim izrazima ne samo... nego/već i vezničkim izrazima nekorelativnog tipa a kamoli, a nekamoli.

\footnotetext{
${ }^{4}$ O isključivosti kao posebnoj vrsti suprotnosti, v. i I. Pranjković, Hrvatska skladnja, Hrvatska sveučilišna naklada, Zagreb, 1993, str.155

${ }^{5}$ M. Stevanović (1974) u svojoj Sintaksi u dilemi je da li su ove rečenice vrsta ili podvrsta. Gramatika i stilistika hrvatskoga ili srpskoga jezika T. Maretića (1899, Zagreb) izdvaja, uz ostale, isključne i zaključne veznike, na kojima će se - kao nosiocima „vrsne semantike“ - temeljiti kasnije izdvajanje isključnih i zaključnih rečenica u sintaksi bosanskog, hrvatskog i srpskog jeezika. Tek 1991. (Sarajevo) pojavit će srednjoškolski udžbenik Naš jezik III (autori M. Kovačević, Č. Rebić, J. Baotić i M. Okuka), u kojoj ovo rečenice nisu „vrsne“ (1981. udžbenik za srednje škole R. Simića Naš jezik $i$ im također ispušta isključne i zaključne iz vrsne grupe nezavisnosloženih), up. M. Kovačević, Sintaksa..., 1993.

${ }^{6}$ Vidjeti napomenu 5.

7 M. Kovačević, Raspred klauza u nezavisnosloženoj rečenici, Zbornik Matice srpske za filologiju i lingvistiku, XXXVI/2, Novi Sada, 1993, 181-206.

${ }^{8}$ Up. J. Silić \& I. Pranjković, Gramatika hrvatskoga jezika, Školska knjiga, 2007.
} 


\section{Objasnidbene rečenične}

Tako je, definirajući jasne kriterije klasifikacije, moderna sintaksa u slavistici distingvirala uglavnom tri vrste nezavisnosloženih rečenica, ${ }^{9}$ ali je ponegdje prepoznala još jednu vrstu koja je po drugima ipak samo podvrsta. To su tzv. objasnidbene (eksplikativne) rečenice ${ }^{10}$ (npr. Mislim, dakle jesam., Počinio je širk, tj. pridrǔ̌io je Bogu druga).

R. Katičić (1986., drugo izd. 1991.) govori o objasnidbenim rečenicama kao posebnoj vrsti nezavisnosloženih (uz sastavne, rastavne, suprotne, ,izuzetne “ i zaključne), koje se vezuju s jer, to, ali i drugim prilozima i priloškim izrazima. M. Kovačević (1993., kasnije izd. 1998.) izdvaja objasnidbene ili „eksplanativne“ rečenice a kao njihove „veznike“ izraze to jest, odnosno i dr. Po I. Pranjković (1984., kasnije izd. 1993.) objasnidbenost je podvrsta sastavnosti, iz čega slijedi da su objasnidbene rečenice podvrsta sastavnih.

M. Velčić (1987.) govori o „tekstnim vezama“ i konektorima pojašnjenja - eksplikativima, tj. konektorima koji se „„čituju samo u tekstu“, pa se onda objasnidbenost i ne iskazuju specijaliziranim vezničkim konektorima kao logičko-gramatičkim sredstvima, već konektorima kao leksikaliziranim kategorijama.

\footnotetext{
9 Status vrste nezavisnosloženih rečenica dobit će, u nekim gramatikama, gradacione rečenice pa će se pojaviti u najnovijim gramatikama bosanskog, kao i hrvatskog i srpskog jezika.

${ }^{10}$ U Gramatici bosanskoga jezika (2000) izdvojene su, među klauzama implicitnih sastavnih rečenica, i objasnidbene klauze, npr. A narod bez vjere je loš narod, zapravo $i$ nije narod (str.418). I u Gramatici hrvatskoga jezika (2007) izvajaju se objasnidbene rečenice kao podvrsta implicitnih (asindetskih) nezavisnosloženih rečenica, npr. Sajam je dvaput godišnje: u proljeće i u jesen ( str. 328).

Nešto ranije, u Htvatskoj skladnji (1993) I. Pranjković rečenice s to jest / tj. uvrštava u strukture implicitne koordinacije, tzv. priključne strukture (,,pod implicitnom koordinacijom razumiju se sve vrste jukstapozicijski složenih struktura kod kojih među dijelovima nema odnosa sintaktičke obaveznosti, tj. kod kojih leksičkosintaksička obilježja jednog dijela nemaju za posljedicu nužnu nazočnost drugoga", str. 147). Ove implicitne (jukstaponirane) strukture izdvojene su prema sredstvima veze: za razliku od eksplicitnih (vezničkih), one se ne povezuju veznicima, a razlikuju se i po slobodnijoj strukturnoj organizaciji i smisaonim odnosima (v. str. 147). Prema tome, I. Pranjković to jest/tj. ne smatra veznikom, gramatikaliziranim sredstvom veze (up. str.148).
} 
Bilo da se o njima govori kao posebnoj vrsti nezavisnosloženih, bilo kao o podvrsti sastavnih, za egzemplifikaciju navode se primjeri s to jest/tj. kao međurečenična veza (uz odnosno, dakle, a zapravo, a u stvari, ili tačnije, bolje, drugim riječima i sl.) ${ }^{11}$

$\mathrm{U}$ ovom radu nas posebno zanimaju upravo objasnidbene rečenice s to jest/tj. i njihova semantika te pitanje jesu li objasnidbene ipak posebna vrsta nezavisnosloženih rečenica ili podvrsta neke od nezavisnosloženih, eksplicitnih (sindetskih, vezničkih) ili implicitnih (asindetskih, bezvezničkih). Analizu ćemo provesti na određenom broju primjera ekscerpiranih iz djela (uže i šire) naučog i publicističkog stila. ${ }^{12}$

\section{Značenje}

Da bi bile posebna vrsta nezavisnosloženih rečenica, kako smo na početku rada vidjeli, potrebno je da i objasnidbene rečenice $u$ složenoj imaju (a) poseban semantički odnos različit od semantičkoga odnosa ostalih nezavisnosloženih rečenica i (b) da ga izražavaju

11 To jest se, ali kao vezno sredstvo na razini teksta, izdvaja u Gramatici hrvatskoga jezika (2007): pripada objasnidbenim ili ekpslikativnim konektorima, koji ,sadržajem rečenice kojoj pripadaju objašnjavaju ili preciziraju sadržaj druge rečenice ili rečenica u tekstu“" (str. 363).

12 Primjeri koje u radu navodimo ekscerpirani su iz sljedećih djela (u našem su tekstu navedeni samo inicijali autora): Abdurahman Nametak, Hrestomatija bosanske alhamijado književnosti, „Svjetlost“", Sarajevo, 1981; Abdurahman Nametak, Fadil-paša Šerifović, Divan, "Svjetlost", Sarajevo, 1981; Midhat Riđanović, Jezik i njegova struktura, „Svjetlost“, Sarajevo, 1985; Džemaludin Latić, Svjetske religije, Priručnik za nastavnike i učenike II. razreda srednjih škola, Bosančica, Sarajevo, 1999; Dževad Jahić \& S. Halilović \& I. Palić, Gramatika bosanskog jezika, Dom štampe, Zenica, 2000; Nirman Moranjak-Baburać, Retorika tekstualnosti, Buybook, Sarajevo, 2003; Midhat Šamić, Kako nastaje naučno djelo, Uvođenje u tehniku naučnoistraživačkog rada - opći pristup, , Svjetlost“, Sarajevo, 2003; Midhat Riđanović, Totalni promašaj, Prikaz Gramatike bosanskoga jezika, Drugo izdanje, „Šahinpašić“, 2003; Esad Duraković \& Lutvo Kurić, Kur'an stilsko $i$ metaforičko čudo, Svjetlostkomerc, Sarajevo, 2006; Tarik Haverić, Čas lobotomije, Prikaz jednog kulturnog skandala, Rabic. eld, Sarajevo, 2007; Sulejman Bulgari, Mi smo jedan drugome najbolji poklon, Cennectum, Sarajevo, 2007; Midhat Riđanović, Praktična gramatika engleskog jezika, 2. dopunjeno izdanje, „Šahinpašić“, Sarajevo, 2007. 
posebnim gramatičkim sredstvima, gramatikaliziranim sredstvima veze (veznicima).

Opće značenje objasnidbenih (su)rečenica je - 'objašnjenje' ili 'eksplikacija' prethodnog sadržaja. Naime, objasnidbene surečenice objašnjavaju, pojašnjavaju, redefiniraju i sl. sadržaj antecedentne surečenice, ili nekog njenog dijela. Sadržaj im je paralelan na poseban način, rekli bismo na neki način sinoniman - kao da je ponovo rečen, preformuliran s neke druge tačke e da bi bio jasniji (čitatelju, općenito primatelju poruke), tj. da bi bio precizniji, određeniji.

Takav, sadržaj se može bez mnogo dvojbe pridružiti značenju 'opće sastavnosti' jer objasnidbenost, pojašnjavanje, preformulacija... podrazumijevaju sličnost, istost, istovrsnost, paralelnost sadržaja - a koja i jeste osnova svakog sastavnog odnosa. ${ }^{13}$ Prema semantičkom kriteriju, tj. smislu, ni ove, objasnidbene rečenice ne bi mogle biti izdvojene kao posebna vrsta među koordiniranim rečenicama.

Naime, iako njihovo značenje (objasnidbenosti) ne izržava ni jedna od drugih nezavisnosloženih rečenica (sastavnim se iskazuju 'sastavni', 'paralelni', 'uzastopni' sadržaji, suprotnim - 'suprotni', 'nepodudarni' sadržaji, a rastavnim - 'paralelni', od kojih je u samo jedan ostvariv, up. Kovačević 1998:13), objasnidbenost se isto tako lahko može podvesti pod opće značenje sastavnosti kao njegova semantička podvrsta. Zato se značenje objasnidbenosti može izdvojiti kao podvrsta značenja sastavnih rečenica.

\section{Veznici}

Imaju li objasnidbene rečenice svoja gramatikalizirana sredstva veze? Je li to jest/ tj. gramatički konektor (veznik) posebnog tipa nezavisnosloženih rečenica (i nerečeničnih struktura) ili spada $u$ negramatikalizirana vezna sredstva (leksička, propozicionalna i sl.)? Je li, dakle, to jest/tj. gramatički veznik objasnidbenih rečenica?

Po nekim je autorima to jest konjunktor koji obrazuje koordinirane sintagme (P. Mrazović i Z. Vukadinović, v. u: Kovačević 1998:60). M. Kovačević (1993./1998.) to jest/tj. tumači kao „čisti

13 Nekima je objasnidbena relacija najbliža disjunktivnoj (v. M. Kovačević, Objasnidbene..., 1998, str. 68) 
veznik objasnidbenih rečenica“, a Pranjković (1993.) izdvaja priključne objasnidbene strukture s to jest kao vrstu implicitnih struktura, npr. Kum Ilija kao da je na našoj strani, tj. uz mene i strica (str. 170). Općenito, izraz to jest/tj. tumači se u literaturi različito, često disparatno:

(a) kao „veznik“ objasnidbenih rečenica (sinaniman ,vezniku“ odnosno) - kao specifično vezno sredstvo jedne vrste nezavisnosloženih rečenica (Kovačević 1993)

(b) kao „konektor pojašnjenja“ (ili „eksplikativ“) - kao jezičko sredstvo kojim se „elementarna rečenica“ povezuje s prethodnom ili prethodnim (Velčić 1987:80)

(c) kao sredstvo veze koje nije veznik, vezno sredstvo par excellence, već spada $\mathrm{u}$ ona sredstva veze kao što su leksičkogramatička, leksička, propozicionalna i sl. pa se (jukstaponirane) strukture koje povezuju svrstavaju u implicitne strukture (Pranjković 1993:147).

Status veznog izraza to jest/tj. različit je dakle: ili je (a) konektor, shvaćeni vrlo široko (uključuje imlicitne rečenice i nerečenične strukture) ili je (b) konjunktor (rečenični veznik par excellence kao gramatikalizirano sredstvom koordinirane veze). Budući da izrazu to jest/tj. nije osnovna funkcija povezivanje (načelno „,najavljuju“ objašnjenje, a prirodu odnosa s prethodnim sadržajem koji pojašnjavaju pokazuje $\mathrm{i}$ anaforički element, pokazna zamjenica to), teško da se može smatrati gramatikaliziranim sredstvom veze, veznikom.

\section{Objašnjenje, pojašnjenje, reimenovanje, redefiniranje, konkretizacija...}

$\mathrm{Na}$ određenom broju primjera iz ekscerpirane građe (određenog broja tekstova naučnog, uže naučnog, stručnog i udžbeničkog tipa, te posebnih tekstova publicističkog stila), pokušat ćemo analizirati semantiku objasnidbenih rečenica s to jest/tj.

Pri tome valja napomenuti da se skraćeni oblik $t j$. javlja isključivo u pismu. (Ortografska pravila predviđaju zarez ispred punog ili skarećenog oblika.) U razgovoru pak to jest može biti 
ispušten, pa objasnidbenu klauzu i nerečeničnu konstrukciju 'najavljuje' kraća pauza na tom mjestu, i intonacija prethodne klauze. Kad je taj vezni izraz „nulti“ u pismu (tj. potpuno ispušten), ulogu „najavljivanja“ često signaliziraju dvotačka ili crta, up.:

Obično se kaže da je tema osnova za izricanje nove obavijesti, to jest/ $\mathbf{t j}$. reme.

Obično se kaže da je tema osnova za izricanje nove obavijesti: reme.

Obično se kaže da je tema osnova za izricanje nove obavijesti - reme.

U razgovoru se, kao i pismu, u ovoj poziciji, često pojavljuje rastavni veznik ili:

Obično se kaže da je tema osnova za izricanje nove obavijesti ili reme.

Značenje 'rastavnosti', koje podrazumijeva izbor (ostvarenje) samo jednog sadržaja, neutralizira se - rekli bismo podrazumijevanim znanjem o podudarnosti, istosti dvaju sadržaja koji su samo iskazani s različitih tačaka imenovanja, tj. reimenovanja (jednog istog referenta), s funkcijom preciziranja, dopunskog pojašnjenja i sl. Tu veznik ili zadržava samo svoje gramatičko značenje 'paralelnosti' dvaju sadržaja (jer su sadržaji 'vraćeni' u 'ravnotežu' iz odnosa u kojem je samo jedan 'ostvariv'), a njega često dodatno, kad to nije posve jasno, signalizira dopuna izrazima tipa drugim riječima, drugačije rečeno i sl. (razg. Ovo je problem ili, drugim riječima, znak da konačno treba nešto mijenjati!) Ona je na neki način tautološka, pa se u pisanom tekstu izbjegava kad je sasvim poznato da je riječ o sinonimnim sadržajima i parafrazi.

Objasnidbene nerečenične konstrukcije (sintagmatske, A) mogu se posmatrati kao rečenične strukture:

A.

1. Dovoljno je da se zna da je vol. skraćenica od volumen, tj. svezak, pa da... (T. H., Čas..., 117)

2. ...iako u nekim stihovima to čini i u mahlas beytu, tj. stihu u kome je utkao svoje ime. (F. N., Fadil-paša..., 69) 
3. ...Kulin-ban je morao izvršiti akt abjuracije, tj. odricanje od bogumilstva pod zakletvom. (Dž.L., Svjetske religije, 131)

4. Obično se kaže da je tema osnova za izricanje nove obavijesti, tj. reme. (Dž.J, S.H, I.P, Gramatika..., 453)

5. Tako u jednom tekstu $\mathrm{u}$ kojem piše o nekim aspektima muslimanskog hodočašća, tj. hadža, Filipović...(T.H., Čas..., 117)

6. Ova funkcija mu je osiguravala mjesto glavnog imama i hatiba, tj. propovjednika u Carevoj džamiji u Sarajevu. (F.N., Fadil-paša..., 19)

7. Filip Hiti navodi da su se Mozarapi tj. ljudi koji prihvataju arapski jezik i običaje...(A. N., Hrestomatija..., 7)

8. Mislim da je posljednji stih svake strofe „Hodte nami vi na viru!“" poziv „na viru“, tj na časnu riječ, „besu“...(A. N., Hrestomatija..., 19)

9. ...mada se kroz pojedine stihove diskretno povlači i prva ideja, tj. poziv na vjeru. (A. N., Hrestomatija..., 19)

10. ...da mu nije cilj ubrati slavu kao književnik nego služiti svom duhovnom vođi-piru (sic!) tj. Džemaludinu Rumiju. (F. N., Fadil-paša..., 40)

11. Određenje granice između teme i reme pretpostavlja barem minimalni kontekst, tj. jedinstvo najmanje dviju rečenica. (Dž. J., S. H., I. P, Gramatika..., 453)

12. Sintaksički i značenjski važnijom smatra se njegova veza $S$ predikatom, tj. njegova adverbijalna uloga. (Dž.J., S.H, I.P, Gramatika..., 451)

13. Istina, naša četvrta pogrešna rečenica ne bi bila negramatična kad bi se poštovati se shvatilo kao poštovati sebe, tj. kao povratni glagol. (M.R., Praktična..., 190)

14. Njegovo je pravo da... koristi islamsku (tj. kur'ansku) terminologiju....(T. H., Čas..., 38)

15. ,...pobio više četalja nego što ima slova u svim kolumnama narodnog poslanika“ (tj. Vešovića, T.H.)... (T.H., Čas..., 99)

Naime, ako se ovakve nerečenične strukture (A) protumače na „kondenzovane“, rečenice nastale postupkom brisanja, tj. ispuštanjem onog što je ponovljeno, redundantno pa stoga i neinformativno $u$ objasnidbenoj rečenici, onda se i takve objasnidbene konstrukcije - 
rečenične ${ }^{14}$, up. Obično se kaže da je tema osnova za izricanje nove obavijesti, tj. reme. i epanaleptično: ${ }^{15}$ Obično se kaže da je tema osnova za izricanje nove obavijesti, t $j$. da je tema osnova za izricanje reme...(up. Velčić 1987:80). Pri tome $t j$. u koordinirananu vezu dovodi dvije („homoformne“) zavisne klauze (da je tema osnova za...), a efekat takvog ponavljanja bi bio, ako se ne radi o tautološkom ponavljanju, intenzifikacija cijele te klauze).

Nerečeničnim objasnidbenim konstrukcijama (navedeni primjeri pod A) pojašnjava se sadržaj prethodne rečenice, tačnije jedan njen dio. Objasnidbena konstrukcija je u sinonimnom odnosu s njim. Po pravilu, jedan rečenični član kao manje poznat termin ili izraz (stranog porijekla, očuđen i na planu grafije npr. kurzivnim načinom pisanja ili slovima, grafijom nekog drugog koda) objašnjen je domaćom ili općepoznatom riječju ili izrazom (npr. mahlas beytu, tj. stihu; skraćenica od volumen, tj. svezak; izvršiti akt abjuracije, tj. odricanje od bogumilstva pod zakletvom). Ili obrnuto, a to je obično onda kad se (gotovo naknadno) objasnidbenim dijelom uvodi zapravo novi termin, uže naučni ili stručni (npr. ...za izricanje nove obavijesti, tj. reme).

Osim toga, objasnidbeni dio često se i ovdje, kao i u objasnidbenim rečenicama, stavlja među zagrade, kao naknadni ili usputni komentar, npr. da koristi islamsku (tj. kur'ansku) terminologiju. Ovakve konstrukcije su i korektivna pojašnjenja (pogotovo u razgovornom diskursu, gdje su neka vrsta naknadnog „ispravljanja“, npr. dolazi četvrtkom, tj. svaki drugi četvrtak). Konstrukcije tog tipa vrlo su česte u dijelovima teksta koji pripadaju napomenama, pogotovo onih koje daju prevoditelji ili redaktori. Da bi postigli preciznost i izbjegli moguće nejasnoće ili prigovore, autori takvih tekstova često se koriste ovakvim konstrukcijama i kao svojevrsnim, dopuštenim ,korektivima“. Onda i ne čudi što ćemo ih nalaziti vrlo često u napomenama (up. npr. napomene u prijevodu Kur'ana Besima Korkuta: ... i on se, tj. Sulejman..., Gospodaru ovog

14 Zato su ,eksplicirane objasnidbene sintagme uvijek implicitne koordinirane rečenične strukture“, M. Kovačević, Objasnidbene (eksplanativne) koordinirane konstrukcije, u: Sintaksa složene rečenice u srpskom jeziku, „Raška škola“, Beograd, 1998, str. 64.

${ }^{15}$ Epanalepsa je figura ,svakojakog“ ponavljanja istih riječi, v. Luka Zima, Figure u našem narodnom pjesništvu, Globus, Zagreb, 1988, str.166 
grada, tj. Mekke..., ...na zapadnoj strani, tj. Sinajskoj gori...; da dožive nesreću zbog jednog novorođenčeta israilskog, tj. zbog Musaa...; A ovi prolaze, tj. a mnogobošci iz Mekke...; A žene njegove su kao majke njegove, tj. žene Muhammedove a.s., glavna knjiga, tj ,Levh mahfuh..., Sekar, tj. džehenem, i najveće čudo, tj. pretvaranje štapa u zmiju; u rukama pisara, tj. meleka...) ${ }^{16}$

Navest ćemo, kao ilustraciju, i ostale primjere objasnidbenih konstrukcija, rečenica s to jest/tj:

B

16. ...taj drugi Ademov (alejhi's-selam) sin počinio je širk, tj. pridružio je Bogu druga“.... (Dž.L., Svjetske..., 120)

17. Složena rečenica pritom mora biti ili monosubjekatska, (tj. klauze moraju imati isti subjekt) ili pa.... (Dž.J, S.H., I.P., Gramatika..., 450)

18. (...dosl. Bila u pravu ili ne, ovo je moja država, tj. ostajem poslušan svojoj državi u svakoj njezinoj akciji, svejedno kakva ta akcija bila) (Dž.L., Svjetske....,123-4);

19. ...i tako je načinjen presedan u povijesti kulture, tj. autor je lišen svoga djela. (T.H., Čas...., 163)

20. ...šsto opet uslovljava da jezik pri izgovoru nenaglašenih vokala ne napravi ,pun pogodak“, tj. ne zauzme položaj koji obično zauzima... (M.R., Jezik...105)

21....i razdor u Kozarcu zbog kojih "ovi serhat neće leći“, tj. stanovništvo se neće smiriti (A.N., Hrestomatija..., 13)

22....jer je prirodno da se refleksija zasniva na modeliranju dominantnog konstruktivnog principa lirike, to jest na pokušaju rekurentnog ,ogoljavanja“ sustava odnosa unutar stiha... (NMB, Retorika..., 149)

B1

23. Drugi znak da slijedimo Učitelja svijeta Muhammeda, s.a.v.s., jeste da se radujemo susretu sa Allahom, dž.š., tj. da više želimo onaj svijet. (S. B., Mi smo..., 138)

24. Stoga se kaže da je on dvofunkcionalna jedinica, tj. da ima atributsko-adverbijalnu narav. (J.Dž., S.H., I.P, Gramatika..., 451)

${ }^{16}$ Kur'an, prijevod Besima Korkuta, Napomene, str. III-XVI. 
25. ...odražava opredjeljenje da se sablazan koju u našoj literaturi predstavlja djelovanje dvojice Filipovića samo prikaže, to jest da se provjerljivi materijalni elementi iznesu i razložno povežu. (T.H., Čas..., 11)

26. U slučaju postanalize radi se, međutim, o posebnom žanru, ...bez obzira na to što se on najčešće konstituira na principu ,žanrovske mimikrije“, to jest, (sic!) najčešće se „maskira“ u manje-više tradicionalne žanrovske strukture. (N. M. B., Retorika...,145);

Može se govoriti o dvama postupcima izražavanja općeg značenja objašnjenja: $\mathrm{s}$ reduplikacijom nekog konstituenta $u$ antecedentu (primjeri 8, 12, 23, 24, 25, 26) i bez reduplikacije (ostali primjeri). A u svim primjerima je riječ o odnosu sintaksičke neobaveznosti: objasnidbena se prema anteriornoj klauzi ne odnosi kao njen konstituent, kao član njene strukture, nego kao semantički i sintaksički neobavezan, dopunski, dodatni, dakle, jednom riječju, objasnidbeni dio.

Da zaključimo. Konstrukcije $\mathrm{s}$ to jest/tj. imaju opće objasnidbeno značenje. U okviru tog općeg značenja mogu se prepoznati određene semantičke (nijansne) razlike s obzirom na odnos konstrukcije s to jest/tj. i antecedenta. (Semantički odnos koordiniranih struktura s izrazom to jest/tj. nijansiran je semantikom samih struktura). To su odnosi:

(a) sinonimnosti:

- nova obavijest, tj. rema

- počiniti širk, tj. pridružiti Bogu druga

Riječ je o postupku reimenovanja, preformulacije radi objašnjenja i pojašnjenja, sa znakom semantičke ekvivalentnosti (poistovjećenja) i izvan konteksta rečenice.

(b) preciziranja, konkretizacija - suženjem značenja:

- (važnim se smatra) njegova veza s predikatom - tj. - njegova adverbijalna uloga

- (da je) dvofunkcionalna jedinica - tj. - da ima atributskoadverbijalnu narav 
- (određenje pretpostavlja) minimalni kontekst - tj.- jedinstvo najmanje dviju rečenica

Riječ je o postupku preciziranja sužavanjem značenja izraženog u antecedentu (npr. u prvom primjeru od ovdje izdvojenih: veza s predikatom može uključiti, osim adverbijalnih, i objekatske „uloge“...). Objasnidbenost ovog tipa (kao svojevrsna 'korekcija suženjem značenja') ostavruje se, unutar iste formalne sintaksičke veze, usporedbom semantike dviju struktura.

(c) (rjeđe) uopćavanja - proširenjem značenja:

- kad bi se poštovati se shvatilo kao poštovati sebe, tj. kao povratni glagol.

Riječ je o postupku pojašnjenja uopćavanjem značenja izraženog $\mathrm{u}$ antecedentu.

I na kraju još i ovo. Koordinacijsko vezno sredstvo to jest/tj. gradi dvokomponentne strukture, jer u koordinacijsku vezu dovodi dvije sintaksičke jedinice ${ }^{17}$ bilo da je riječ o sintagmama (A) ili klauzama (B, B1). Pri tome obasnidbene konstrukcije s to jest/ $t j$. mogu biti i izostavljene, a da to ne utiče na gramataičnost ostatka rečenice (prethodne klauze) ni na njihovu semantičku samostalnost.

$U$ rečenicama i nerečeničnim konstrukcijama $s$ veznim izrazom to jest ostvaruju se i sadržaj prethodne i sadržaj objasnidbene - „drugim riječima iskazane“ klauze. Objasnidbeni sadržaj time ne postaje komunikativno inferiorniji, on je naprosto jednak - samo iskazan s različite tačke. Ipak, moguću „komunikativnu drugost“ može pokazati to što se objasnidbena rečenica, kao i nerečenična konstrukcija, može ispustiti, a da se značenjska samostalnost prethodne klauze ne dovede u pitanje. Značenje „drugosti“ nije proizašlo iz posteriorne pozicije objasnidbene klauze ili konstrukcije $u$ rečenici, već iz sinonimnosti sadržaja (već jedanput) iskazanaog (makar i s druge pozicije imenovanja istog referenta) u prethodnoj klauzu ili nekom njenom dijelu. (Sadržaj veznog elementa to jest t $t$. može se opisati kao 'još jednom, ponovo o već rečenom', 'isto što i': nova obavijest $=$ rema, abjuracija $=$ odricanje od..., dvofunkcionalna

${ }^{17}$ Up. M. Kovačević, Objasnidbene...., str. 62 
= ima atributivno-adverbijalnu..., ali se on kao neobavezni strukturni element lahko može ispustiti.)

Iako je riječ o objasnidbenom i dopunskom, značenje konstrukcije i rečenice s veznim elementom to jest/tj. komunikativno može biti i značajnije od onog koje nosi antecedentna klauza kao cjelina ili neki njen član/članovi, npr. kao kad je riječ o korektivnom objašnjenju kao dopuni karakterističnoj više za usmeni, kolokvijalni diskurs, nego za pisani (Dolazi obično četvrtkom, to jest svakog drugog četvrtka, razg.).

Objasnidbene strukture s antecedentnim obrazuju formalnostrukturnu cjelinu, čiju koherentnost pojačava ponavljanje bar jednog strukturnog elementa iz prethodne klauze, odnosno naporedna (paralelna) veza tih klaza: bez obzira na to što se on najčešće konstituira na principu ,žanrovske mimikrije“, to jest, najčešće se „,maskira"; izgovoru nenaglašenih vokala ne napravi ,pun pogodak", tj. ne zauzme položaj... To se javlja i odbjasnidbenim konstrukcijama (A): smatra se njegova veza s predikatom, tj. njegova adverbijalna uloga;

$\mathrm{Na}$ svoj način koherentnost se iskazuje i kad vezno to jest/tj. dolazi ispred subordiniranog veznika ( $d a)$ postajući signal reduplikacije zavisnih klauza (antecedentne i objasnidbene) i nositelj njihovog koordinacijskog odnosa (v. Kovačević 1998), npr.: Stoga se kaže da je on..., tj. da ima...; odražava opredjeljenje da se sablazan..., to jest da se provjerljii...; Drugi dan da slijedimo..., da više želimo...(primjeri B1).

Objasnidbene konstrukcije rezultat su nastojanja da se bude jasan, precizan do kraja, da se izbjegnu moguće nejasnoće, da se udovolji zahtjevu tačnosti. Vezni element to jest/tj. zadaje referentnu jednakost objasnidbene konstrukcije i dijela u antecdentu ili cijele prethodne klauze, pa na neki način ,zadržavaju pažnju na istom“, usporavaju razvoj teme (prethodne klauze).

To jest/tj. i odnosno su sinonimni (može se provjeriti postupkom zamjene ovih veznika u prethodnim primjerima), ali bilo 
bi zanimljivo istražiti odnos ovih veznih sredstava i drugih koji bi se mogli naći u istoj poziciji (tačnije rečeno, u stvari, drugim riječima...). Posebno se zanimljivim za semantiku sintakse može pokazati istraživanje odnosa značenja objasnidbenih konstrukcija i odredbenih sintagmi (apozitivnih konstrukcija) kad se, kao i u objasnidbenim konstrukcijama, „dva puta imenuje“ isti referent (denotat). A čini nam se da značajna mogu biti istraživanja značenja korektivne dopune i preformulacije objasnidbenih konstrukcija u razgovornom (kolokvijalnom) stilu.

\section{Literatura}

1. Jahić, Halilović, Palić 2000 - S. Halilović, Dž. Jahić, I. Palić, Gramatika bosanskog jezika, Do štampe, Zenica, (Ismail Palić je autor dijela Sintaksa u Gramati), 417-422

2. Katičić 1991 - R. Katičić, Sintaksa hrvatskoha književnoga jezika, Nacrt za gramatiku, Hrvatska akademija znanosti i umjetnosti, Razred za filološke znanosti, knj. 61, Zagreb, 171172

3. Kovačević 1993 - M. Kovačević, Raspred klauza u nezavisnosloženoj rečenici, Zbornik Matice srpske za filologiju i lingvistiku, XXXVI/2, Novi Sada, 1993, 181-206.

4. Kovačević $\mathbf{1 9 8 6}$ - M. Kovačević, Gradacione rečenice za nerealizovnu suprotnost u srpskohrvatskom jeziku, Naučni sastanak slavista u Vukove dane 15/1, MSC, Beograd, str. 103115

5. Kovačević 1987 -M. Kovačevič, Gradacione konstrukcije u Vukovom $i$ današnjem jeziku, Zbornik radova o Vuku Stefanoviću Karadžiću, Institut za jezik i književnost u Sarajevu, Sarajevo, str. 225-228

6. Kovačević 1993 M. Kovačević, Objasnidbene koordinirane konstrukcije, Zb. Matice srpske za filologiju $i$ lingvistiku, XXXVI/2, Novi Sad, 99-121

7. Kovačević $\mathbf{1 9 9 8}$ - M. Na svoj način to se ostvaruju i kad vezno to jest/tj. dolazi ispred subordiniranog veznika ( $d a)$ postajući signal reduplikacije zavisnih klauza (antecenedtne i objassnidbene) i nositelj njihovog koordinacijskog odnosa (v. Kovačević 1998), npr.: Stoga se kaže da je on..., tj. da ima...; 
odražava opredjeljenje da se sablazan...,to jest da se provjerljii...; Drugi dan da slijedimo..., da više želimo...(primjeri B1).

8. Kovačević, Sintaksa složene rečenice u srpskom jeziku, „Raška škola“, Beograd

9. Pranjković 1984 - I. Pranjković, Koordinacija u hrvatskom književnom jeziku, Znanstvena biblioteka Hrvatskog filološkog društva 13 , Zagreb

10. Silić 1984 - J. Silić, Od rečenice do teksta, Sveučilišna naklada Liber, Zagreb

11. Silić, Pranjković 2007 - Gramatika hrvatskoga jezika, Školska knjiga, str.320- 328

12. Velčić - M.Velčić, Uvod u lingvistiku teksta, Školska knjiga, Zagreb, str.72-83

13. Zima 1988 - Luka Zima, Figure u našem narodnom pjesništvu, Globus, Zagreb, 1988, str.166 
Prof. dr. Remzija Hadžiefendić-Parić

\section{EXPLICATIVE SENTENCE AND NON SENTENCE STRUCTURES IN BOSNIAN LANGUAGE WITH "TO JEST "}

SUMMARY

This study relates to semantic and structural characteristic of explicative sentence and non sentence constructions identified by conjunction medium "to jest".

Specific qualities of explicative sentence include meanings of explanation, addition, redefinition, reformulation, and coordinated relation (grammar independence).

Study aims to determine are explicative sentences a special variety of explicative independently complex sentences (to jest represents a formal indication of such relation, an independent conjunction which is a quality of explicative sentence), or they represent a sub specie of implicit independently complex sentences (to jest does not attain status of specific independent conjunction and postponed clause with conjunction to jest is introduced by method of enumeration).

Sentences with to jest are very often manifested in scientific writing style articles, as well as in essays which use a form of repetition - a consequence of deliberate intention - in order to achieve additional intelligible effect, precision, and correctives.

Key words: explicative sentence, redefinition, reformulation, addition, corrective, conjunction medium, conjunction, to jest, independently complex sentence, scientific writing style, publicist writing style. 


$$
\text { أ. د. رمزية حاج أفنديتش - باريتش }
$$

\section{الجمل التفسيرية (التوضيحية) والتراكيب غير الجملية المتضمنة لأدوات "بععنى" أو "يعني" في اللغة البوسنوية}

\section{خلاصة البحث}

يتناول البحث الخصائص الدلالية والتركيبية لتراكيب الجمل التفسيرية وغير الجمل التي تتميز

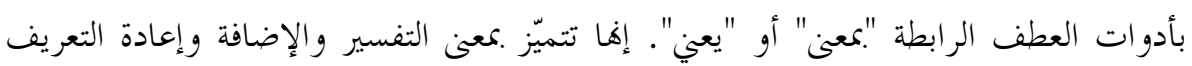

$$
\text { و التحديد، مع العلاقة التنسيقية (الاستقلال النحوي). }
$$

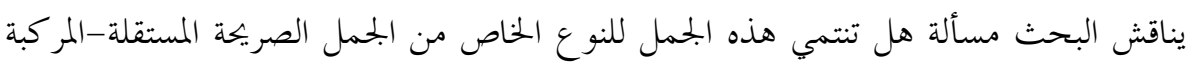

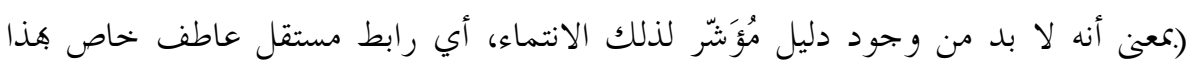

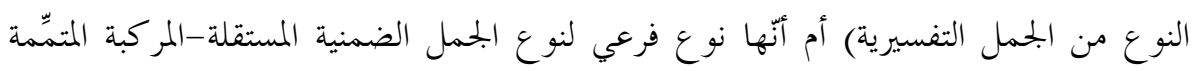

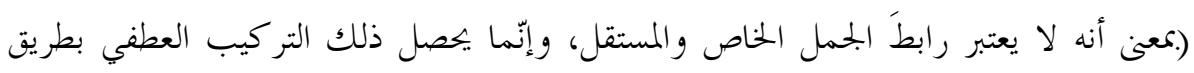
التتابع لا التنظيم).

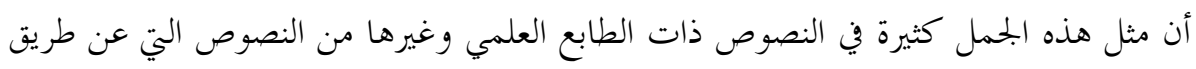
التكرار المتعمد يرفع من شأن الوضوح والدقة والتصحيح المعيّن. 